\title{
Performance of different modules on yield, nutrient uptake and physico-chemical properties of soil after harvest of greengram (Vigna radiata L.)
}

\author{
A.H. Sipai*, Kuldeep Sevak, Kotramma Addangadi and A. N. Chaudhary \\ Regional Research Station (S.D.A.U.) BHACHAU- KACHCHH (GUJARAT) INDIA \\ (Email : sipaisoil@gmail.com)
}

\begin{abstract}
A field experiment was conducted at Regional Research Station, SDAU, Bhachau, Kachchh to study the performance of different modules on yield, uptake and physico- chemical properties of soil after harvest in greengram (Vigna radiata $\mathrm{L}$.) Experiment consisted of five different modules among three were organic modules, one was chemical module and control, under Randomized Block Design. The results of the experiments differed significantly. The significant improvement in yield attributes and yield was recorded with the chemical module $\mathrm{T}_{4}$. In organic modules $\mathrm{T}_{2}$ and $\mathrm{T}_{3}$ recorded the highest growth improvement and yield as compared to control. Modules $\mathrm{T}_{2}$ and $\mathrm{T}_{3}$ also recorded the good nutrient content and uptake. Available nutrients in the soil after harvest were best in the organic modules $\left(\mathrm{T}_{2}\right.$ and $\left.\mathrm{T}_{3}\right)$ maintained the soil physico-chemical properties by reducing the soil bulk density.
\end{abstract}

Key Words : Greengram, Organic module, Chemical module, Yield, Nutrient uptake, Physico-chemical property

View Point Article : Sipai, A.H., Sevak, Kuldeep, Addangadi, Kotramma and Chaudhary, A.N. (2018). Performance of different modules on yield, nutrient uptake and physico-chemical properties of soil after harvest of greengram (Vigna radiata L.). Internat. J. agric. Sci., 14 (1) : 106-111, DOI:10.15740/HAS/IJAS/14.1/106-111.

Article History : Received : 25.07.2017; Revised : 15.11.2017; Accepted : 28.11.2017

\footnotetext{
* Author for correspondence:
} 